\title{
A Case Study Analysis of Typhidot: An Example of Market-Oriented R\&D Commercialization in Malaysia
}

\author{
Baharudin Kadir $^{1}$ \& Mohd Farid Shamsudin ${ }^{1}$ \\ ${ }^{1}$ Marketing Department, Universiti Kuala Lumpur Business School, Kuala Lumpur, Malaysia \\ Correspondence: Baharudin Kadir, Universiti Kuala Lumpur Business School, Marketing Department, Level 13, \\ Bangunan Yayasan Selangor, No. 74, Jalan Raja Muda Abdul Aziz, Kg. Baru, 50300 Kuala Lumpur, Malaysia.
}

Received: April 30, 2019

doi:10.5430/ijfr.v10n5p75
Accepted: May 30, 2019

Online Published: June 10, 2019

URL: https://doi.org/10.5430/ijfr.v10n5p75

\begin{abstract}
Background and objective: despite many empirical studies on the success factors for R\&D commercialization in the past few decades, the success rates have not improved significantly. Possible explanations for this could be that the processes involved and how these interact with other components of the commercialization ecosystem at the different commercialization phases are not well understood yet. Market-oriented approach to R\&D commercialization was proposed in this study as a possible way of increasing the success rates of commercialization. Materials and methods: the case study approach was proposed to provide insights into the commercialization processes and how these interact with other components of the commercialization ecosystem. Typhidot, an acknowledged market-oriented R\&D commercialization was selected for the case study. Results: the findings indicated different challenges at different phases of the $R \& D$ commercialization journey and many of the processes at the different phases were iterative in nature. A " $Z$ to A" market-oriented R\&D commercialization framework was proposed based on the Typhidot case study. Conclusion: while the " $\mathrm{Z}$ to A" approach was important basis for market-oriented R\&D commercialization the study also highlighted the strategic choices of scaling up and the impact of the choice on business viability. A wrong scaling-up strategy would influence the diffusion rate and extent of R\&D commercialization, which ultimately determined whether it would succeed or fail in the market place.
\end{abstract}

Keywords: market-oriented R\&D commercialization, case study, Typhidot, commercialization ecosystem, Malaysia

\section{Introduction}

The field of R\&D commercialization has gained considerable importance in the last fifty years; however, it has become especially significant in the last two decades when governments realized that in an ever increasing globalized world, nations and not just firms have to become competitive. And the key to national competitiveness is the ability of a country's economy to create new businesses which depends to a large extent on innovations; these in turn, are often the outcomes of successful R\&D commercialization (see for examples, Ritchie Abidin et al, 2016; Adisetiawan, 2018).

The national measure of R\&D intensity is the Gross Expenditure on R\&D/GDP ratio (GERD/GDP); a higher ratio indicates higher relative spending on R\&D. While higher GERD/GDP ratio in itself does not translate into higher success rates of R\&D commercialization, given equal rates of commercialization success, countries with higher ratios would be able to generate higher number of innovations and thus, are more likely to be able to produce new businesses which in turn, positively impact economic growth.

Despite numerous empirical studies that identified specific factors contributing to higher rates of successful R\&D commercialization (see for examples Adnan Hye and Islam (2013); Adusah-Poku, (2016) MOSTI (Ministry of Science, Technology \& Innovation), (2012) and Aguilar-de Borja, (2018) the rates have not improved that significantly in the past decades, ranging from single-digit $\%$-ages to more than $20 \%$, depending on industry and level of economic development, e.g. about $5 \%$ for Institutions of Higher Learning \& Government Research Institutes in Malaysia (Ahmad 2018; Ahmed et al, 2018), to more than 20\% at Stanford\& MIT in US (Aimer (2016)).

Ministry of Science, Technology and Innovation, Malaysia, MOSTI (Mohd Yusob, et.al.2015; Aina and Ayodele, 2018) has identified the following challenge to be addressed so that the benefits and effectiveness of research funded by public R\&D expenditure in Malaysia will achieve better returns: 
- While there were significant technical contributions in science and technology (S\&T) activities, the majority of $R \& D$ projects were not market-oriented and thus, not readily exploitable for commercial application (Lewrick et al, 2011).

This study attempts to understand some of the dimensions of a market-oriented R\&D commercialization project by means of a case study. A framework derived from the case study would provide guidelines for a market-oriented R\&D commercialization.

\section{Methodology}

The fact that the rates of successful R\&D commercialization have remained relatively low despite extensive empirical studies conducted in the area in the last several decades, suggests that perhaps:

(1) the processes involved and how these interact with other components of the innovation ecosystem (such as access to different types of funding at different phases of commercialization, availability of the "right" entrepreneurs, government \& institutional policies, customers, suppliers, etc.), and/or,

(2) country-specific (and industry-specific) factors, such as the different mix and intensity of the various components of the innovation ecosystem and how these would influence the success rates of R\&D commercialization, are not well understood yet.

Thus, a deeper understanding of this "commercialization journey" by means of the case study approach would help in providing context for the factors that contribute to successful $R \& D$ commercialization as found in many of the empirical research conducted on this topic to date (for discussion on case study research design and methods, refer to Akgun and Tektufekci, 2017; Natsheh et al, 2015; Akhir et al, 2018; OECD, 2013; Aldulaimi and Abdeldayem, 2018 demonstrates how a portfolio of case study research designs fits differently to a theory continuum - theory understanding, theory-building, theory development, and theory testing; for recent examples of the use of case study research on technology R\&D commercialization, refer to Ale, 2018; Booz Allen Hamilton, 2012; Pellikka and Malinen, 2014).

Typhidot (Note 1) was selected as an exemplar of an acknowledged case of successful market-oriented R\&D commercialization in order to map its commercialization journey so that a clearer picture of the processes and interactions involved among the various components of its innovation ecosystem could be better understood. It presented a good case of market-oriented $\mathrm{R} \& \mathrm{D}$ commercialization that started at a public university and was successfully developed based on matching qualified market needs to the right R\&D activities and appropriate choice of technology platform (Ridder, 2017) (Yin, 2014).

\section{Results}

The market needs and the design and development criteria of the market place are already evident and the R\&D undertaken (and the appropriate technology platform) was geared towards this requirement, i.e. a market-oriented R\&D commercialization. Market needs for Rapid Diagnostic Tests stated as criteria for design and development given the challenge of low resource settings are listed below:

- $\quad$ Specific

- Sensitive

- $\quad$ Easy to perform

- Built-in-controls

- Cost effective

- $\quad$ No refrigeration

- $\quad$ No culture facilities

- Minimal lab infrastructure

- Lack of electricity

- $\quad$ Lack of trained personnel

- Have to be transported without cold chain

The challenge was then to "reverse-engineer" the needs and requirement of the market place to the right product using the appropriate technology platform (the "Z-to-A" approach). Identifying the components of the "missing links" between "Z" (market needs \& requirement) and "A" (R\&D with the right technology platform) and how these 
components interact with each other and other players of the innovation ecosystem provides insights into what it takes for a market-oriented R\&D commercialization to materialize (refer to Figure 1: "Z" to "A" approach in R\&D commercialization).

R\&D activities, technology platform and prototype stages: The process of getting the right link between the "market needs and requirement" $(Z)$ to the appropriate "R\&D activities and technology platform" (A) is iterative in nature. A research team was formed in 1987 at the Institute for Research in Molecular Medicine, Universiti Sains Malaysia (USM) comprising of Dr. Asma Ismail, Dr. Ong Kok Hai and Dr. Zainoodin Sheikh A. Kader; each researcher focused on specific area of the disease, i.e. typhoid fever and they worked closely with clinicians and paediatricians for testing (Ritchie, 2000).

The breakthrough technology came about with the discovery of antigens specific for typhoid diagnosis. The discovery of the $50 \mathrm{kDa}$ outer membrane protein specific for Salmonella typhi was reported in 1991 by Ismail, Ong \& Kader (Chandran, 2010) (Zhang, 2013). This was an important discovery that led to the development of a rapid dot enzyme immunosorbent assay (EIA) kit called TYPHIDOT TM for the rapid detection of specific IgM and $\operatorname{IgG}$ to S. typhi within 3 hours compared to 2-5 days via conventional diagnostic methods (Choo, Ismail, Ong and Oppenheimer, 1994). The product went through extensive testing with clinicians and paediatricians before it was produced on a commercial scale.

More generous funding at this stage was made possible by the Ministry of Science, Technology and Innovation (MOSTI) in the form of the Intensification of Research in Priority Areas (IRPA) grants; previously, research grants were limited to only RM 20,000 (Rogers, 2003).

Scaling-up and commercial start-up stages: Professor Dr. Ong Kok Hai of the research team formed a partnership with the Malaysian Technology Development Corporation (MTDC) in 1994 to set up Malaysian Bio-Diagnostic Research Sdn. Bhd. (MBDR) to commercialize Typhidot.At the Commercial Start-up Stage Typhidot kits were made available to the open market worldwide. Some of the challenges at this stage included the following:

- Teething issues in terms of production and logistics, e.g. the need to use leak-proof bottles for rough logistics in rural areas - these had to be imported;

- Increasing the buy-in from users and prospects - the researchers had to present their research papers to various stakeholders in the key markets, e.g. India and Pakistan;

- The need to constantly upgrade the technology to shorten testing time;

- On-going improvement to make the product "idiot-proof" and user-friendly;

- Emerging competition from copy-cat products;

- The need to expand product offerings using the rapid test platform, e.g. diagnostics for specific drug abuse for the police force (Wouters, 2010).

Funding at these stages was provided by the Malaysian Technology Development Corporation (MTDC) in the form of Technology Acquisition Fund (TAF); MTDC was also a substantial shareholder in the start-up company (Swamidass, 2013).

Figure 1 summarizes the major phases of the market-oriented R\&D commercialization for Typhidot; the phases are characterized by numerous iterations back to the identified market needs. 


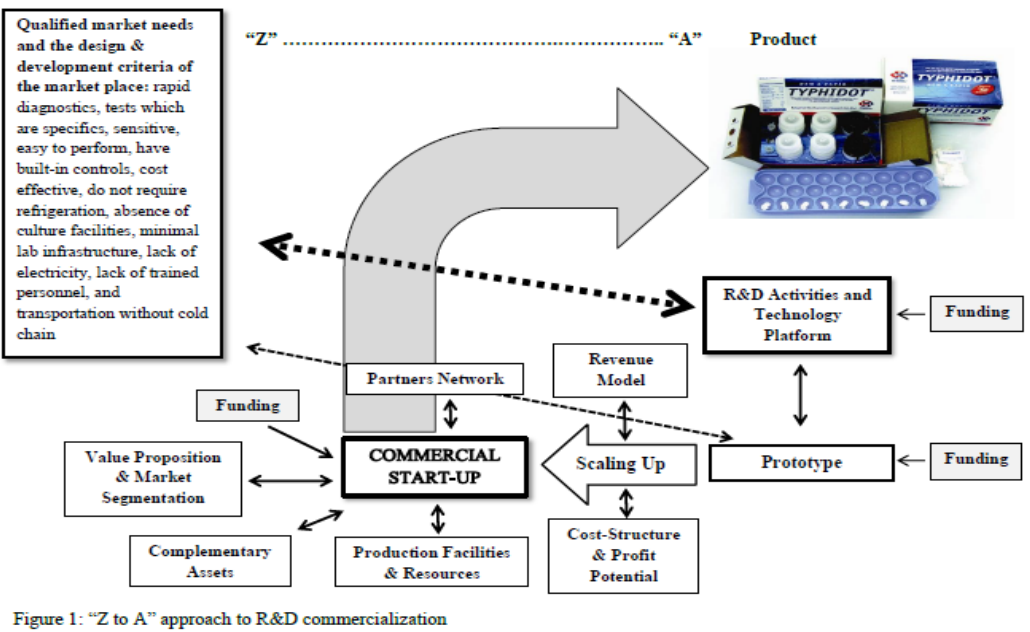

Figure 1. "Z to A" approaches to R\&D commercialization

\section{Discussion}

Typhidot is an example of a market-oriented R\&D commercialization that started with a set of qualified market needs culminating in the appropriate technology platform which formed the basis for the product development. The TYPHIDOT Rapid Diagnostic Tool Kit that was finally developed actually delivered the required needs of the marketplace; in this sense the R\&D commercialization was indeed market-oriented and a successful one up to that phase, i.e. Commercial Start-Up.

However, to grow beyond the start-up phase requires the usual business management skills, i.e. developing, qualifying and delivering the right value proposition to the target markets, having the right business and profit models, etc.; in short, the ability to develop the right strategies and executing those strategies better than the competitors. This is when the new product is able to go through the innovation diffusion curve as proposed by Rogers (Dmitriev et al, 2014), (Van Hemert et al, 2013), i.e. innovation adoption by innovators to early adopters to early majority, etc. The reality is, not many new products that are the results of R\&D commercialization are able to cross over the "chasm" or "the valley of death" from the introduction stage to the rest of the innovation curve. This then begs the question: where is the cut-off point of a successful market-oriented R\&D commercialization - is it at the commercial start-up phase or the ultimate ability to go through the whole innovation diffusion curve? This question is still much debated among those responsible for innovation and commercialization in academia and research organizations.

Some of the commercialization challenges identified in this case were similar to ones found in the study by Eisenhardt and Graebner (2007) for the health sector, namely, access to capital, need for entrepreneurial skills and difficulty in navigating the complexities of the markets.

The fact that the start-up company (MBDR) did not quite turn profitable within 4-5 years after its founding indicates that some of the internal and external resources and capabilities that it was supposed to secure and develop did not or were slow to materialize (and these in turn had adversely affected its business operations in terms of revenues, cash flow and profitability).

The commercialization path taken by Typhidot, i.e. from R\&D to a business start-up to market the product was the most straight forward option, but at the same time it was the most risky. Market development challenges especially in terms of getting the product accepted by the target end-users (e.g. small rural hospitals in developing and less-developed countries where typhoid fever is endemic) and having it widely distributed to make it accessible in appropriate outlets could well be beyond the capability of a start-up. Even if it could be done, the time it takes to get to the critical mass (in terms of sales and profitability levels to justify initial investment in the commercial start-up) would create issues with regards to working capital and cash flow. These could have adverse effects on the start-up as a viable ongoing business entity. 
Some recent studies suggested that collaborative commercialization could reduce the risks and improve chances of success especially for small firms (see for example Ismail et al, 1991). Other possible options would include licensing (see for example Adusah-Poku, 2016) and alliance with more established firms (see for example Aguilar-de Borja, 2018).

The route to successful R\&D commercialization is fraught with many challenges; getting the right product that meets the needs of the market place is not the end of it. In fact it is the beginning of the next challenge of marketing it to the right target customers, profitably - the other 3 of the 4P's of marketing come into play: the right Price, making it available at the right Place (distribution channels) and the right Promotion (creating awareness and branding).

The challenges at the Commercial Start-Up Phase were very similar to the ones highlighted by Ale (2018) in their study on business development in the commercialization of technology innovations. These challenges are in fact quite similar to any business start-up (and not necessarily unique to a start-up arising from R\&D commercialization) and they include the following (Ale (2018)):

- Developing and delivering a qualified business value proposition to the target market

- Striking the right balance between cost structure and profit potential

- Justifying the appropriate production facilities and securing the required resources

- Developing optimal revenue model and complementary assets

- Expanding partners networks

Figure 2 summarizes the essential elements of market-oriented R\&D commercialization, incorporating its major phases as well as the challenges that need to be overcome.

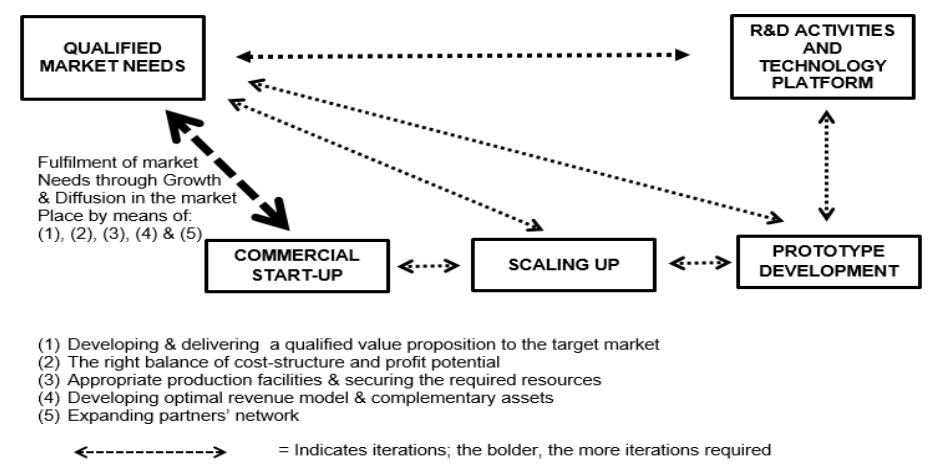

Figure 2. Essential elements of market-oruented R\&D commercialization framework

Overcoming these challenges would ensure the diffusion of the commercialized product or technology in the marketplace; otherwise it will end up in the "death valley" of the innovation diffusion curve. The faster and more extensive the diffusion, the earlier the business entity would be able to recoup its investment and increase its survival in the market place.

\section{Conclusion}

Despite its early commercialization potential, the internal and external challenges faced by MBDR the commercial start-up company for Typhidot, were just overwhelming and resulted in continuing losses; by 1999-2000 MTDC took over the management of the company. With hindsight and considering the various challenges and constraints faced by the start-up company, a less risky route to commercialization could have been by licensing or a joint venture with an already established player in the pharmaceutical industry.

The established partner would have the necessary knowledge as well as the technical and market infra-structure to mitigate the "teething problems" faced by the start-up company so as to ensure a smooth innovation diffusion of the product in the marketplace. 


\section{Significance Statement}

This study discovered that while successful market-oriented $R \& D$ commercialization depends a lot on fulfilling the needs of the market place, other aspects of the different phases of the commercialization cycle, especially the commercial start-up phase is equally if not more important since it would ensure the diffusion of the commercialized product or technology in the marketplace. This study would help further research in the field of R\&D commercialization by providing insights into the critical market and business challenges faced by the start-up at the different phases of the commercialization journey.

\section{Acknowledgement}

The authors would like to thank Professor Datuk Dr. Asma Ismail and Professor Dr. Ong Kok Hai, two of the three scientists who discovered the breakthrough technology that became the basis for Typhidot commercialization and Mr. Ambok Chening Meri, the first Chief Executive Officer of MBDR for agreeing to share their experiences in the Typhidot commercialization journey.

\section{References}

Abidin, I. S. Z., Haseeb, M., Chiat, L. W., \& Islam, M. R. (2016). Determinants of Malaysia-BRICS trade linkages: gravity model approach. Investment Management and Financial Innovations, 13(2), 1-10. https://doi.org/10.21511/imfi.13(2-2).2016.14

Adisetiawan, R. (2018). Does Stock Split Influence to Liquidity and Stock Return? (Empirical Evidence in the Indonesian Capital Market). Asian Economic and Financial Review, 8(5), 682-690.

Adnan Hye, Q. M., \& Islam, F. (2013). Does financial development hamper economic growth: empirical evidence from Bangladesh. Journal of Business Economics and Management, 14(3), 558-582.

Adusah-Poku, F. (2016). Carbon dioxide emissions, urbanization and population: empirical evidence from Sub-Sahran Africa. Energy Economics Letters, 3(1), 1-16.

Aguilar-de Borja, J. M. (2018). Teacher Action Research: Its Difficulties and Implications. Humanities \& Social Sciences Reviews, 6(1), 29-35. https://doi.org/10.18510/hssr.2018.616

Ahmad, S. D. (2018). Legal Protection Carried Out by the Financial Service Authority in a Dispute between Consumers and Insurance Companies in Indonesia. International Journal of Social and Administrative Sciences, $3(1), 55-61$.

Ahmed, A., Rehan, R., Chhapra, I. U., \& Supro, S. (2018). Interest rate and financial performance of banks in Pakistan. International Journal of Applied Economics, Finance and Accounting, 2(1), 1-7. https://doi.org/10.33094/8.2017.2018.21.1.7

Aimer, N. M. M. (2016). Social sciences institute, department of business administration, Kastamonu University, Turkey. Energy Economics Letters, 3(3), 30-41. https://doi.org/10.18488/journal.82/2016.3.3/82.3.30.41

Aina, J. K., \& Ayodele, M. O. (2018). The Decline in Science Students' Enrolment in Nigerian Colleges of Education: Causes and Remedies. International Journal of Education and Practice, 6(4), 167-178. https://doi.org/10.18488/journal.61.2018.64.167.178

Akgun, L., \& Tektufekci, F. (2017). Audit in Russian Federation and the Research Toward the Determination of the Functioning of Audit Mechanism. Asian Journal of Economic Modelling, 5(1), 23-34. https://doi.org/10.18488/journal.8/2017.5.1/8.1.23.34

Akhir, R. M., Ahmad, S. N. B., Ahmad, H., \& Hashim, N. A. (2018). Staying or Leaving? The Influence of Employees' Engagement towards Turnover Decision Among Employees of A Semi-Government Organization in Malaysia. American Journal of Social Sciences and Humanities, 3(1), 55-62. https://doi.org/10.20448/801.31.55.62

Aldulaimi, S. H., \& Abdeldayem, M. M. (2018). The Economic Value of Time in Arab Culture: New Evidence using Zimbardo Time Perspective Inventory (ZTPI). American Journal of Social Sciences and Humanities, 3(1), 63-72. https://doi.org/10.20448/801.31.63.72

Ale, A. S. (2018). Assessment of Dual Carriageway for Sustainable Socio-Economic Development in Ado Ekiti, Nigeria. International Journal of Sustainable Development \& World Policy, 7(1), 27-36. https://doi.org/10.18488/journal.26.2018.71.27.36 
Booz Allen Hamilton. (2012). Accelerating commercialization of cost-saving health technologies. California HealthCare Foundation, Robert Wood Johnson Foundation, \& von Liebig Center for Entrepreneurism and Technology Advancement.

Chandran, V. G. R. (2010, November-December). R\&D commercialization challenges for developing countries: the case of Malaysia. Tech Monitor, 25-30.

Choo, K. E, Ismail, A., Ong, K. H., \& Oppenheimer, S. J. (1994). Rapid serodiagnosis of typhoid fever by dot immunoassay in an endemic area. Clin Infect Dis, 19, 172-6. https://doi.org/10.1093/clinids/19.1.172

Dmitriev, V., Simmons, G., Truong, Y., Palmer, M., \& Schenekenberg, D. (2014). An exploration of business model development in the commercialization of technology innovations. $R \& D$ Management, 40(3), 306-323.

Eisenhardt, K. M., \& Graebner, M. E. (2007). Theory building from cases: opportunities and challenges. Academy of Management Journal, 50, 25-32. https://doi.org/10.5465/amj.2007.24160888

Ismail, A., Ong, K. H., \& Abdul Kader, Z. (1991). Demonstration of an antigenic protein specific for Salmonella typhi. Biochem. Biophys. Res. Comm., 181, 301-305. https://doi.org/10.1016/S0006-291X(05)81417-2

Lewrick, M., Omar, M., \& William, R. L. Jr. (2011). Market orientation and innovators' success: an exploration of the influence of customer and competitor orientation. Journal of Technology Management \& Innovation, 6(3), 48-61. https://doi.org/10.4067/S0718-27242011000300004

Mohd Yusob, M. L., Salleh, M. A., Haron, A. S., Makhtar, M., Asari, K. N., \& Jamil, L. S. M. (2015). Maqasid al-Shariah as a Parameter for Islamic Countries in Screening International Treaties before Ratification: An Analysis. Pertanika Journal of Social Sciences \& Humanities, $23: 219-226$.

MOSTI (Ministry of Science, Technology \& Innovation). (2012). National science and technology policy (2013-2020). Putrajaya.

Natsheh, A. A., Gbadegeshin, S. A., Rimpiläinen, A., IImamovic-Tokalic, I., \& Zambrano, A. (2015, January). Identifying the challenges in commercializing high technology: a case study of quantum key distribution technology. Technology Innovation Management Review.

OECD. (2013). Effectiveness of research and innovation management at policy and institutional levels, Cambodia, Malaysia, Thailand and Vietnam.

Pellikka, J. T., \& Malinen, P. (2014). Business models in the commercialization processes of innovation among small high-technology firms. International Journal of Innovation and Technology Management, 11(2), 1-21.

Ridder, H.-G. (2017). The theory contribution of case study research designs. Business Research, 10, 281-305.

Ritchie, B. K. (2000). Innovation systems, collective dilemmas, and formation of technical intellectual capital in Malaysia, Singapore and Thailand. Paper delivered at the Center for Management of Innovation and Technopreneurship, National University of Singapore.

Rogers, E. M. (2003). Diffusion of innovations (5th ed.). The Free Press, New York.

Swamidass, P. (2013). University start-ups as a commercialization alternative: lessons from three contrasting case studies. Journal of Technology Transfer, 38, 788-808. https://doi.org/10.1007/s10961-012-9267-6

Van Hemert, P., Nijkamp, P., \& Masurel, E. (2013). From innovation to commercialization through networks and agglomerations: analysis of sources of innovation, innovation capabilities and performance of Dutch SMEs. Annual Register of Science, 50, 425-452. https://doi.org/10.1007/s00168-012-0509-1

Wouters, M. (2010). Customer value propositions in the context of technology commercialization. International Journal of Innovation Management, 14(6), 1099-1127. https://doi.org/10.1142/S1363919610003021

Yin, R. K. (2014). Case study research: design and methods (5th ed.). London, Thousand Oaks: Sage Publications.

Zhang, J.-F. (2013, April-June). International comparison of national innovation system efficiency. Tech Monitor, 23-29.

\section{Note}

Note 1. Typhidot is a revolutionary method of diagnosis invented in Malaysia. It uses a more sensitive Enzyme Immunoblot Assay for the detection of human IgG and $\mathrm{IgM}$ antibodies against a specific $50 \mathrm{kDa}$ antigen on the outer membrane of S. typhi. Typhidot has been evaluated at many endemic areas including Malaysia, India, Indonesia, Pakistan and Philippines. 